\title{
Upaya Meningkatkan Kecerdasan Kinestetik Anak Usia Dini Melalui Kegiatan Menari pada Kelompok B di RA Al-Ikhlas Medan
}

\author{
Khadijah $^{1}$, Sapri², Khotimatul Majidah ${ }^{3}$ \\ Pascasarjana Universitas Islam Negeri Sumatera Utara \\ 3hotimatulmajidah28@gmail.com
}

\begin{abstract}
This study aims to determine the improvement of early childhood kinesthetic intelligence through dancing activities in group $B$ in $\mathrm{R} A$ Al-Ikblas Medan. This research was conducted in group $B$ at $\mathrm{R} A$ Al-Ikblas Medan with a total of 13 children conducted in the second semester of T.A 2017/2018. This research uses participant's classroom action research methods. This study consisted of two cycles, each cycle consisting of 3 meetings. Data analysis uses quantitative and qualitative data. Quantitative data analysis with descriptive statistics that compares the results obtained from the Pre Cycle, the first cycle and the second cycle. Qualitative data analysis by analyzing data from observations during the study. In the pre cycle $23.1 \%$, the first cycle increased to $38.5 \%$ and the second gycle became $84.6 \%$. The result showed an increase in early childhood kinesthetic intelligence in group B which was carried out through dancing activities.
\end{abstract}

Keywords: Kinesthetic Intelligence, Dancing, Motor

\begin{abstract}
ABSTRAK
Penelitian ini bertujuan untuk mengetahui peningkatan Kecerdasan Kinestetik anak usia dini melalui kegiatan menari pada kelompok B di RA Al-Ikhlas Medan. Penelitian ini dilaksanakan pada kelompok B di RA Al-Ikhlas Medan dengan jumlah 13 orang anak yang dilaksanakan pada semester II T.A 2017/2018. Penelitian ini menggunakan metode penelitian tindakan kelas partisipan. Penelitian ini terdiri dari dua siklus, masing-masing siklus terdiri dari 3 kali pertemuan. Analisis data menggunakan data kuantitatif dan kualitatif. Analisis data kuantitatif dengan statistik deskriptif yaitu membandingkan hasil yang diperoleh dari Pra Siklus, Siklus pertama dan Siklus kedua. Analisis data kualitatif dengan cara menganalisis data dari hasil observasi selama penelitian. Pada pra siklus 23,1\%, siklus I meningkat menjadi 38,5\% dan siklus II menjadi $84,6 \%$. Hasil penelitian menunjukkan adanya peningkatan kecerdasan kinestetik anak usia dini pada kelompok B yang dilakukan melalui kegiatan menari.
\end{abstract}

Kata Kunci: Kecerdasan Kinestetik, Menari, Motorik 


\section{PENDAHULUAN}

Terdapat didalam buku Frames of mind, tahun 1983 Gardner menampilkan Theory Of Multiple Intelligence dikutip dari Cambell,dkk (2006:2) yang memperkuat perspektifnya tentang kognisi manusia yang meliputi diantaranya kecerdasan kinestetik yang berkaitan dengan kemampuan menggunakan gerak seluruh tubuh untuk mengekspresikan ide dan perasaan serta keterampilan mempergunakan tangan untuk menciptakan atau mengubah sesuatu dan memiliki nilai estetika. Demikian dalam kaitannya dengan pertumbuhan dan perkembangan fisik anak, pemerintah mulai memperhatikan setiap tumbuh kembang anak. Seperti yang tertulis dalam Kurikulum Raudhatul Athfal Tahun 2016 tentang Perkembangan Fisik Anak Usia Dini yang mengatakan tingkat pencapaian anak usia 5-6 Tahun yaitu:

Mengenal anggota tubuh dan fungsinya, melakukan gerakan terkoordinasi secara terkontrol, seimbang,dan lincah, melakukan gerakan mata, tangan, kaki, kepala secara terkoordinasi dalam menirukan berbagai gerakan yang teratur (misal:senam dan tarian) melakukan permainan fisik dengan aturan, terampil menggunakan tangan kanan dan kiridalam berbagai aktivitas (mengancingkan baju, menali sepatu, menggambar, menempel, menggunting pola, meniru bentuk, menggunakan alat makan.

Berdasarkan hasil Observasi yang dilakukan penulis di $\mathrm{Ra}$ Al- Ikhlas Medan menunjukkan bahwa strategi pembelajaran yang digunakan memberikan perlakuan yang sama kepada semua anak, tanpa melihat perbedaan kecerdasan masing-masing anak. Salah satu penyebabnya adalah lingkungan belajar yang kurang mendukung, kurangnya kepedulian dan keterkaitan guru dalam meningkatkan kecerdasan kinestetik anak, anak terlihat tidak suka belajar dengan terlibat secara langsung, artinya anak hanya duduk dan diam , selebihnya anak kurang lincah, anak merasa bosan, cepat lelah dan konsentrasi anak tidak fokus, Sehingga tidak meningkatnya rasa ingin tahu anak. Pembelajaran dengan melibatkan anak dapat membantu meningkatkan kecerdasan kinestetik anak.

Berkaitan dengan hal tersebut, maka penulis mencoba menggunakan pembelajaran dan kegiatan yang belum ada di kelasnya, yaitu dengan kegiatan menari. Menari disini disesuaikan dengan kebutuhan dan perkembangan anak usia dini yang nantinya membuat anak untuk tertarik dengan kegiatan ini, Penulis memilih menari "Kids Islamic" karena menari ini adalah salah satu kegiatan yang aktivitasnya merupakan aktivitas gerak fisik, 
diharapkan dengan adanya kegiatan menari ini kemampuan Kecerdasan Kinestetik anak pada kelompok B di Ra Al-Ikhlas Medan T.A 2017/2018 dapat meningkat.

\section{METODE}

Penelitian ini menggunakan metode penelitian tindakan kelas partisipan. Penelitian ini terdiri dari dua siklus, masing-masing siklus terdiri dari 3 kali pertemuan. Analisis data menggunakan data kuantitatif dan kualitatif. Analisis data kuantitatif dengan statistik deskriptif yaitu membandingkan hasil yang diperoleh dari Pra Siklus, Siklus pertama dan Siklus kedua. Analisis data kualitatif dengan cara menganalisis data dari hasil observasi selama penelitian dengan instrumen yang telah dibuat oleh penulis sebagai ajuan dalam mengobservasi anak agar dapat terlihat setiap peningkatan yang terjadi pada anak.

\section{PEMBAHASAN}

\section{Kecerdasan Kinestetik}

Kecerdasan Kinestetik menurut Gardner dalam Cambell (2006:75) adalah kemampuan untuk menyatukan tubuh dan pikiran untuk menyempurnakan pementasan fisik yaitu kecerdasan yang berkaitan dengan kemampuan gerak motorik dan keseimbangan, sejalan dengan pendapat Armstrong dalam Musfiroh (2008:170) bahwa Kecerdasan kinestetik dapat dirangsang melalui permainan-permainan yang memungkinkan anak bergerak dengan tumpuan otot dan keseimbangan dan keluwesan dan kelenturan serta gerakan-gerakan cekatan motorik halus seperti menjahit, melukis, menulis, atau menganyam. Menurut Madyawati (2014:22) Kecerdasan Kinestetik merupakan suatu kecerdasan, ketika saat menggunakan seseorang mampu atau terampil menggunakan anggota tubuhnya untuk melakukan gerakan seperti Menari, Berlari, melakukan kegiatan Seni dan Hasta karya. Berdasarkan dari beberapa pendapat ahli, dapat disimpulkan bahwa Kecerdasan Kinestetik merupakan Kemampuan menggunakan seluruh tubuh untuk mengekspresikan ide dan perasaan.

\section{Menari}

Menurut Hawkins dalam Suyadi (2014:132) tari merupakan Ekspresi perasaan manusia yang diubah oleh imajinasi dan diberi bentuk oleh media gerak sehingga menjadi 
gerak simbolis sebagai ungkapan penciptaannya, sejalan dengan La Mery dalam Suyadi (2014:132) Tari merupakan gerak-gerak yang diberi bentuk dan ritmis dari badan ke dalam ruang. Menurut Kamaladevi Chattt Opadhaya dalam Yulianti (2009:3) Tari merupakan gerakan-gerakan yang ritmis yang lama kelamaan mengarah kepada bentuk-bentuk tertentu. Menurut Susanne K. Langer dalam Yulianti (2009:3) Menari merupakan gerak-gerak yang dibentuk secara ekspresif agar dapat dinikmati dengan rasa. Menurut Jhon Martin dalam Yulianti (2009:3) Menari merupakan perwujudan suatu tekanan emosi dalam bentuk gerak tubuh. Berdasarkan dari pendapat para ahli di atas dapat disimpulkan bahwa Menari adalah bentuk pengekspesikan terhadap suatu emosi.Tari Kreasi merupakan bentuk gerak tari baru yang dirangkai dari perpaduan tarian.

\section{Motorik}

Istilah Motorik dalam Masganti (2015:91) merujuk pada faktor biologis dan mekanis yang mempengaruhi gerak. Istilah gerak merujuk pada perubahan aktual yang terjadi pada bagian tubuh yang diamati, sejalan dengan pendapat Mansur dalam Fadillah (2011:28) Motorik adalah segala keterampilan anak dalam menggerakkan dan menyeimbangkan tubuhnya. Berdasarkan dari bebrapa pendapat di atas dapat disimpulkan bahwa Motorik merupakan setiap gerakan tubuh yang melibatkan otot-otot besar maupun kecil yang dapat berpindah/mengubah posisi.

\section{Hasil Temuan dan Pembahasan}

\section{Pra Siklus}

Tabel 1. Rangkuman Hasil Observasi Kecerdasan Kinestetik Anak pada Pra Tindakan

\begin{tabular}{c|c|c|c|c}
\hline No & $\begin{array}{c}\text { Skor } \\
\text { Rata-Rata }\end{array}$ & $\begin{array}{c}\text { Jumlah } \\
\text { Anak }\end{array}$ & $\begin{array}{c}\text { Persentase } \\
\text { Nilai Anak (\%) }\end{array}$ & Keterangan \\
\hline 1. & $19-24$ & 0 & 0 & $\begin{array}{c}\text { Berkembang Sangat } \\
\text { Baik (BSB) }\end{array}$ \\
\hline 2. & $13-18$ & 0 & 0 & $\begin{array}{c}\text { Berkembang Sesuai } \\
\text { Harapan (BSH) }\end{array}$ \\
\hline 3. & $7-12$ & 3 & 23,1 & $\begin{array}{c}\text { Mulai Berkembang } \\
\text { (MB) }\end{array}$ \\
\hline 4. & $0-6$ & 10 & 76,9 & $\begin{array}{c}\text { Belum Berkembang } \\
\text { (BB) }\end{array}$ \\
\hline \multicolumn{2}{r|}{ Jumlah } & $\mathbf{1 3}$ & $\mathbf{1 0 0}$ & \multicolumn{2}{c}{} \\
\hline
\end{tabular}


Tabel 1. Menunjukkan hasil pengamatan pada pra tindakan, terdapat dari 13 anak, 3 anak masih dikatagorikan belum berkembang (23,1\%), 10 anak mencapai kriteria mulai berkembang $(76,9 \%)$. penulis melihat bahwa kecerdasan kinestetik anak mulai berkembang sehingga tergambar dalam bentuk diagram batang sebagi berikut:

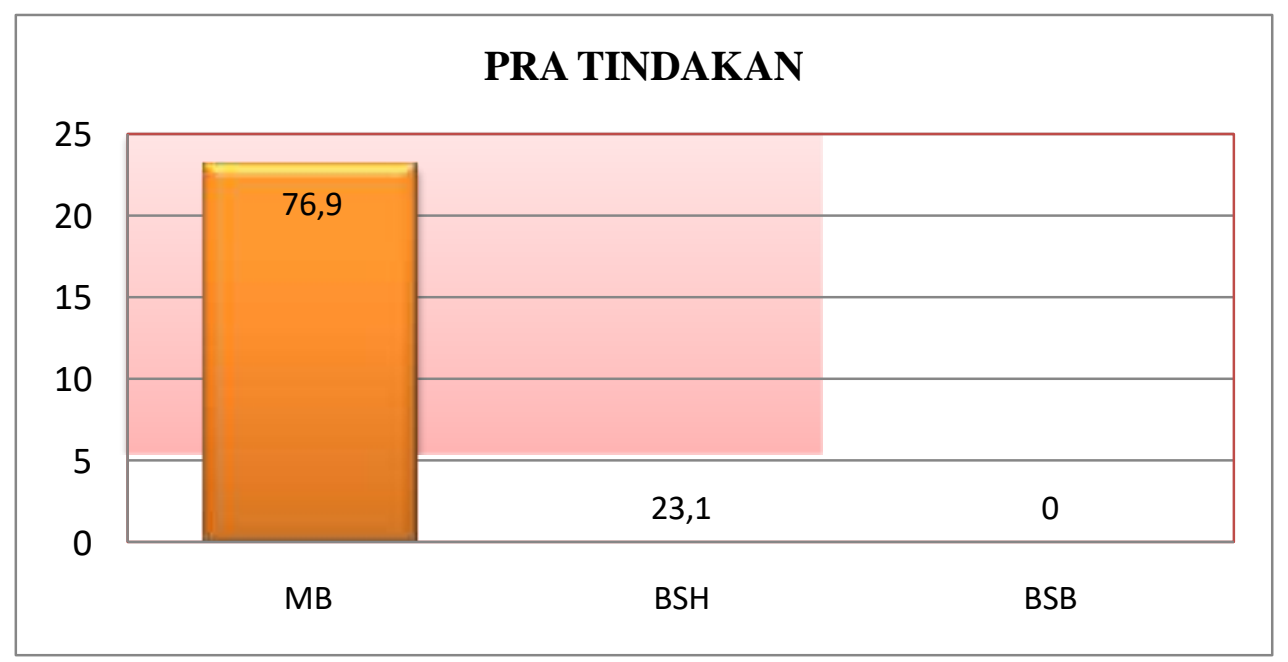

Gambar 1. Diagram Batang Peningkatan Kecerdasan Kinestetik Anak pada Pra Tindakan

Gambar 1. Menunjukkan hasil pengamatan pada pra tindakan, terdapat dari 13 anak, 3 anak masih dikatagorikan belum berkembang (23,1\%), 10 anak mencapai kriteria mulai berkembang $(76,9 \%)$.

\section{Siklus I}

Tabel 2. Rangkuman Hasil Observasi Kecerdasan Kinestetik Anak Pada Siklus I Pertemuan III

\begin{tabular}{ccccc}
\hline No & $\begin{array}{c}\text { Skor } \\
\text { Rata-Rata }\end{array}$ & $\begin{array}{c}\text { Jumlah } \\
\text { Anak }\end{array}$ & $\begin{array}{c}\text { Persentase Nilai } \\
\text { Anak }(\%)\end{array}$ & Keterangan \\
1. & $19-24$ & 0 & 0 & $\begin{array}{c}\text { Berkembang Sangat } \\
\text { Baik ( BSB })\end{array}$ \\
2. & $13-18$ & 5 & 38,5 & $\begin{array}{c}\text { Berkembang Sesuai } \\
\text { Harapan ( BSH) } \\
\text { Mulai Berkembang } \\
\text { 3. }\end{array}$ \\
4. & $0-12$ & 8 & 61,5 & $\begin{array}{c}\text { (MB) } \\
\text { Belum Berkembang } \\
\text { (BB) }\end{array}$ \\
\hline \multicolumn{2}{c}{ Jumlah } & 13 & 0 & 100 \\
\hline
\end{tabular}

Tabel 2. Menunjukkan bahwa hasil observasi pada siklus I pada pertemuan I, II dan III, penulis melihat bahwa terdapat peningkatan pada kecerdasan kinestetik anak sudah 
dapat mencapai kriteria berkembang sesuai harapan. Pada pertemuan III terdapat 8 anak mulai berkembang dan 5 anak berkembang sesuai harapan, maka dari itu dapat dilihat peningkatan kecerdasan kinestetik anak pada diagram batang di bawah ini :

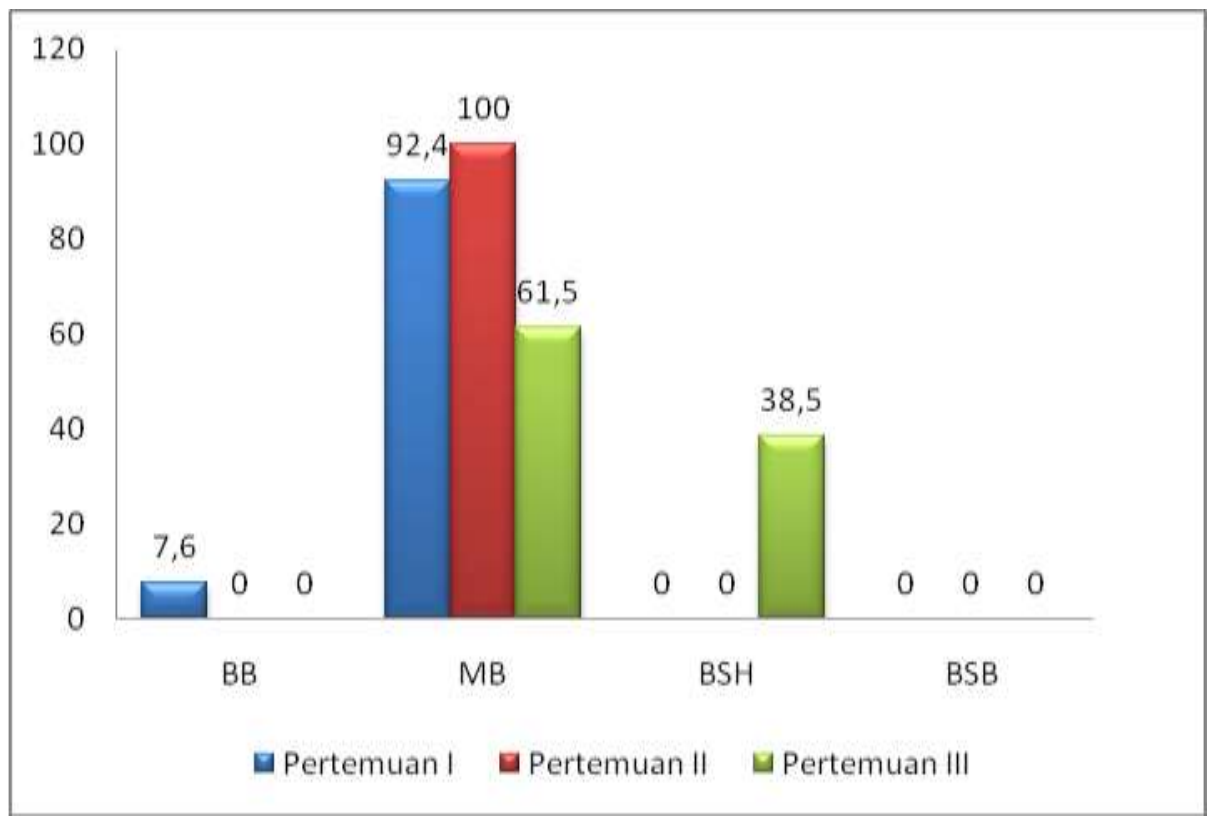

\section{Gambar 2. Diagram Batang Peningkatan Kecerdasan Kinestetik Anak pada Siklus I pertemuan I, II dan III}

Gambar 2. Menunjukkan bahwa persentase kemampuan klasikal pada Siklus I telah mencapai $38,5 \%$.

\section{Siklus II}

Tabel 3. Rangkuman Hasil Observasi Kecerdasan Kinestetik Anak Pada Siklus II Pertemuan III

\begin{tabular}{|c|c|c|c|c|}
\hline No & $\begin{array}{c}\text { Skor } \\
\text { Rata-Rata }\end{array}$ & $\begin{array}{l}\text { Jumlah } \\
\text { Anak }\end{array}$ & $\begin{array}{c}\text { Persentase Nilai } \\
\text { Anak }(\%)\end{array}$ & Keterangan \\
\hline 1. & $19-24$ & 11 & 84,6 & $\begin{array}{c}\text { Berkembang Sangat } \\
\text { Baik ( BSB ) }\end{array}$ \\
\hline 2. & $13-18$ & 2 & 15,4 & $\begin{array}{c}\text { Berkembang Sesuai } \\
\text { Harapan }(\mathrm{BSH})\end{array}$ \\
\hline 3. & $7-12$ & 0 & 0 & $\begin{array}{l}\text { Mulai Berkembang } \\
(\mathrm{MB})\end{array}$ \\
\hline 4. & $0-6$ & 0 & 0 & $\begin{array}{l}\text { Belum Berkembang } \\
\text { (BB) }\end{array}$ \\
\hline & Jumlah & 13 & 100 & \\
\hline
\end{tabular}

Tabel 3 Menunjukkan bahwa hasil observasi pada siklus II pada pertemuan I, II dan III, penulis melihat bahwa terdapat peningkatan pada kecerdasan kinestetik anak sudah dapat mencapai kriteria berkembang sangat baik. Pada pertemuan III terdapat 2 anak 
mencapai kriteria berkembang sesuai harapan dan 11 anak berkembang sangat baik, maka dari itu dapat dilihat peningkatan kecerdasan kinestetik anak pada diagram batang di bawah ini :

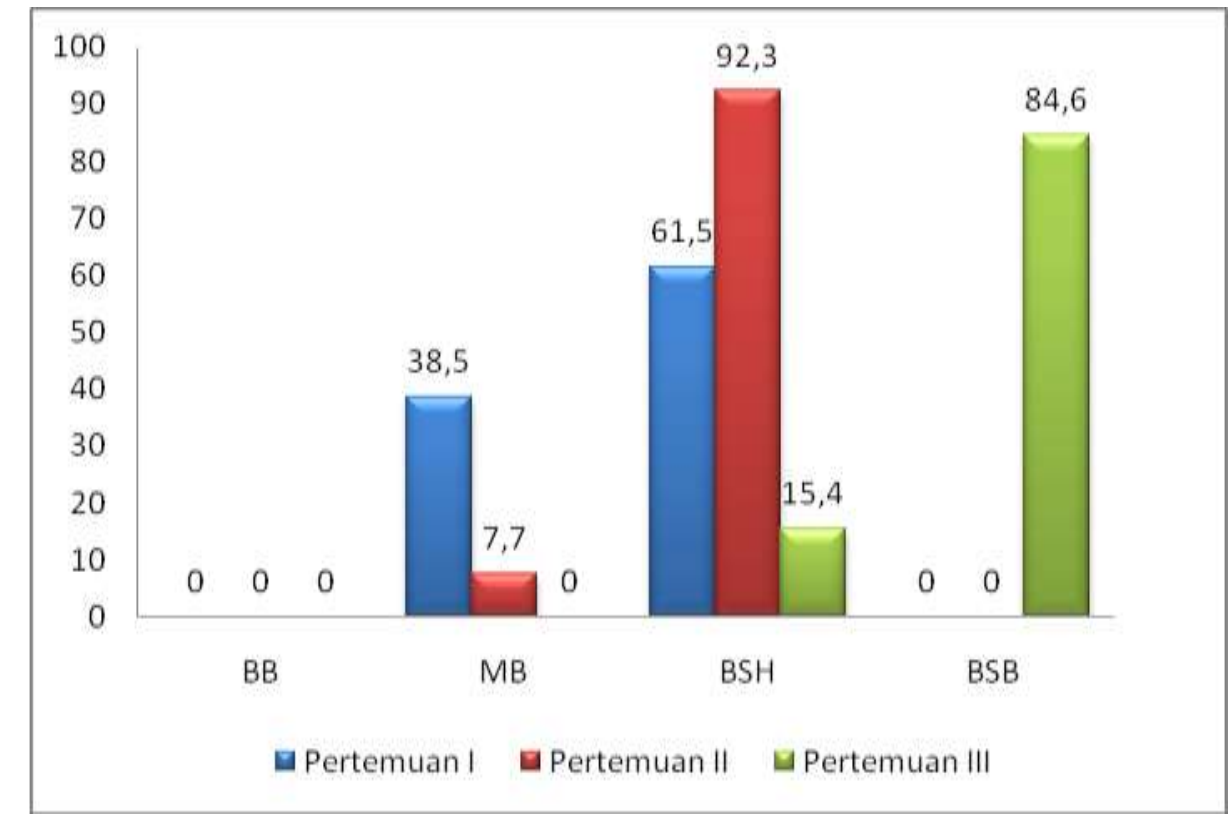

Gambar 3. Diagram Batang Peningkatan Kecerdasan Kinestetik Anak pada Siklus II pertemuan I, II dan III

Gambar 3. Menunjukkan Persentase Kemampuan Klasikal pada Siklus II Yaitu 84,6\%.

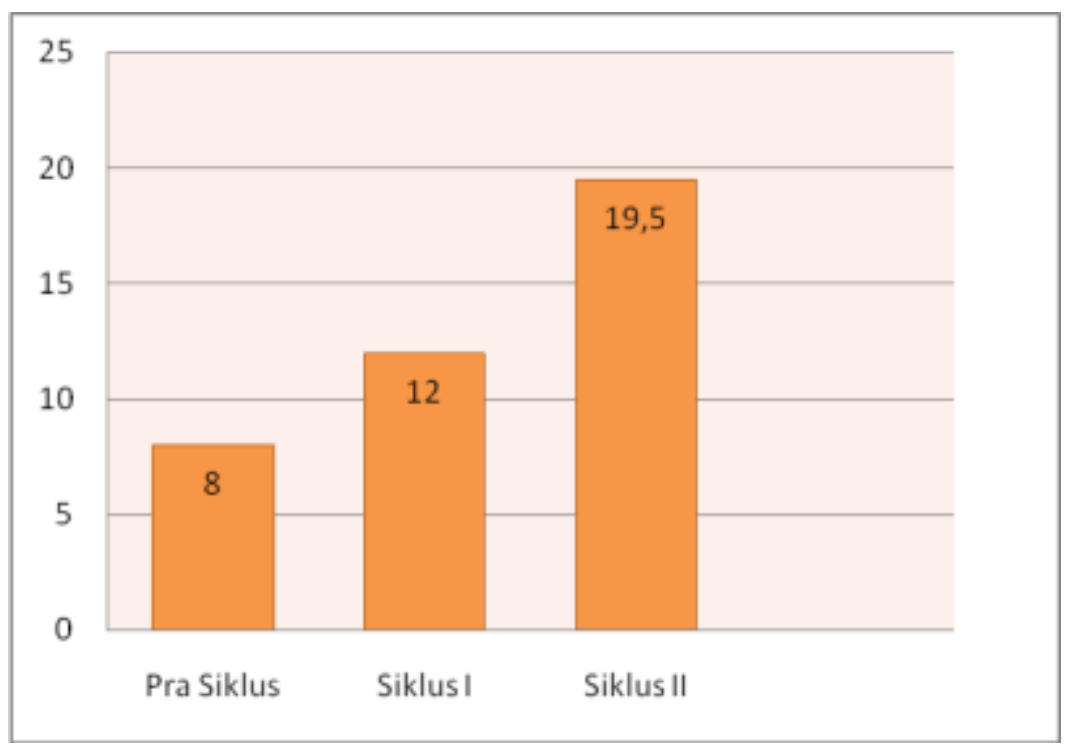

Gambar 4. Diagram Batang Nilai Rata-Rata Hasil Observasi Peningkatan Kecerdasan Kinestetik Anak pada Pra Siklus, Siklus I, dan Siklus II

Gambar 4. Menunjukkan bahwa terjadinya peningkatan kecerdasan Kinestetik melalui kegiatan menari. 
Dari penelitian yang dilakukan mulai pada Pra siklus Siklus I dan Siklus II menunjukkan bahwa rata-rata anak mengalami peningkatan. Peningkatan pada kecerdasan kinestetik anak memperlihatkan bahwa dengan menggunakan kegiatan menari kids Islamic lebih efektif digunakan dalam meningkatkan kecerdasan kinestetik anak.

Hasil penelitian ini didukung oleh Gardner dalam Cambell (2006:2) yang menyatakan bahwa perkembangan intelegensi kinestetik dengan mudah dapat dilihat jika kita mengamati para Aktor, Atlit atau Penari, dengan melihat dari indikator yang diterangkan oleh Gardner meliputi Koordinasi, Keseimbangan, Kekuatan, Ketangkasan, Kecepatan dan Fleksibilitas yang dijadikan sebagai indikator penilaian obsevasi oleh penulis. Dengan demikian kegiatan menari merupakan salah satu upaya yang dapat meningkatkan kecerdasan kinestetik anak usia dini pada kelompok B.

\section{KESIMPULAN}

Berdasarkan hasil observasi terhadap penelitian tindakan kelas yang dilakukan selama 2 siklus diperoleh beberapa kesimpulan yaitu : (1) Kecerdasan kinestetik anak usia 5-6 tahun sebelum adanya kegiatan menari di Ra Al-Ikhlas Medan masih menacapai kriteria mulai berkembang, hal ini dilihat dari hasil observasi penulis pada saat pra siklus dari 13 anak, 3 anak masih mencapai kriteria belum berkembang (23,1\%), 10 anak mencapai kriteria mulai berkembang $(76,9 \%)$ dan belum ada anak yang mencapai kriteria berkembang sesuai harapan dan kriteria berkembang sangat baik. Dengan begitu anak telah mencapai nilai rata-rata 8,3. Kondisi ini menunjukkan bahwa kecerdasan kinestetik anak usia 5-6 tahun mulai berkembang. (2) Pelaksanaan kegiatan Menari di Ra Al-Ikhlas Medan dilakukan dengan 2 siklus, yaitu siklus I dan siklus II dengan masing-masing siklus terdiri dari 3 pertemuan. Pada siklus I anak melakukan kegiatan menari dengan bimbingan guru dan penulis sedangkan pada siklus II anak melakukan kegiatan menari dengan temantemannya tanpa di bimbing oleh guru dan penulis. (3) Kegiatan menari dapat meningkatkan Kecerdasan Kinestetik anak usia 5-6 tahun di RA Al-Ikhlas Medan, hal ini dapat dilihat dari hasil penelitian selanjutnya yang dilakukan oleh penulis hingga siklus II. Pada siklus I, 8 anak mencapai kriteria mulai berkembang (61,5\%), 5 anak mencapai kriteria berkembang sesuai harapan $(38,5 \%)$ dan adapun persentase kemampuan klasikal pada siklus I memperoleh 38,5\%. Pada siklus II, 2 anak mencapai kriteria berkembang sesuai harapan (15,4\%), 11 anak mencapai kriteria berkembang sangat baik $(84,5 \%)$ dan adapun persentase kemampuan klasikal pada siklus II yaitu 84,5\%. Berdasarkan hasil penelitian di atas 
menunjukan bahwa dengan adanya kegiatan menari pada siklus I hingga siklus II diperoleh peningkatan. Inilah yang menunjukkan bahwa kecerdasan kinestetik anak usia 5-6 tahun pada kelompok B menjadi meningkat setelah adanya kegiatan menari di RA Al-Iklhas Medan Tahun Ajaran 2017/2018.

Berdasarkan temuan maka dapat disarankan dalam penelitian ini agar lebih mengedepankan kreatifitas anak dalam mengembangkan segala aspek penilaian agar agar lebih tertarik dan tidak bosan dengan media yang di sajikan.

\section{REFERENSI}

Cambell, Linda dkk (Bruce Campbell\&Dee Dickinson), (2006), Metode Praktis Pembelajaran Berbasis Multiple Intelligences, Jakarta: Intuisi Press.

Musfiroh, Tadkiroatun, (2008), Cerdas Melalui Bermain, Yogyakarta.

Madyawati, Lilis, (2016), Strategi Pengembangan Bahasa Pada Anak, Jakarta: Kencana.

Masganti, (2015), Psikologi Perkembangan Anak Usia Dini, Medan: Perdana Publishing.

Fadillah, (2012), Desain Pembelajaran Paud. Jogjakarta: Ar-Ruz Media. 